\title{
Państwowa, narodowa, społeczna, partyjna? Nauczanie historii w szkołach publicznych - studium przypadku
}

\begin{abstract}
Bardzo się cieszymy, że dyskutujemy o problemie kształcenia i historii w szkołach [...] Przypadajaca w sobotę rocznica sowieckiej agresji na Polskę uzmysławia nam, jak ważny jest problem nauczania historii i patriotyzmu
\end{abstract}

M. Migalski (konferencja prasowa PJN, wrzesień 2011 r.) ${ }^{1}$

1 września 2009 r. zainaugurowana została w Polsce wieloletnia reforma oświaty. Zmiany, których wprowadzenie zakłada, zostaną w pełni wdrożone we wrześniu 2014 r. - wówczas zapisy znowelizowanej ustawy o systemie oświaty ${ }^{2}$ oraz poszczególnych rozporządzeń ministerialnych obejmą wszystkie etapy edukacyjne. Reforma, ujmując tę kwestię najogólniej, ma na celu upowszechnienie wychowania przedszkolnego, obniżenie wieku obowiązku szkolnego, modyfikację treści podstaw programowych oraz ramowych planów nauczania, wreszcie praw i obowiązków nauczyciela. Tak, jak i każda inna, jest wyrazem określonej polityki rządu, dokonującego świadomych przekształceń, w tym wypadku w obszarze edukacji publicznej. Rozpoczęta przez minister Katarzynę Hall, kontynuowana przez jej następczynię minister Krystynę Szumilas, była i jest przedmiotem wielu ocen pozytywnych oraz - nie mniej licznych - negatywnych.

Tematem tego artykułu będzie niewielki obszar, w stosunku do wszystkich dokonanych zmian, a mianowicie zreformowane nauczanie przedmiotu historia. Kwestia ta stała się osią sporu politycznego, jak i przyczyną wielu akcji społecznych, opowiadających się zarówno za proponowanym przez MEN kształtem reformy, ale przede wszystkim negujących założenia przedstawione przez Ministerstwo.

Specyfiką badanego obszaru, jest nie tylko nauczanie historii, ale szersza w stosunku do niego polityka historyczna państwa jako polityka szczegółowa. Za Edgarem Wolfrumem, należy stwierdzić, że może ona mieć charakter oświeceniowy, emancypacyjny, ale również pełnić funkcje manipulacyjne. Niewątpliwie historia uwierzytelnia polityke, a polityka historię $^{3}$. Kategorie takie, jak ,polityka historyczna”, „strategia pamięci”, „polityka wobec przeszłości”, „,polityka pamięci”, czy „polityka tożsamości”, są od lat coraz bardziej obecne w analizach politologicznych. Niestety objętość artykułu nie pozwala nawet na pobieżny przegląd stanowisk poszczególnych badaczy ${ }^{4}$, wobec powyższego - tekst ma na celu stano-

\footnotetext{
${ }^{1}$ Gazeta.pl, PJN: więcej godzin historii w szkołach, http://wiadomosci.gazeta.pl/wiadomosci/1,114873, 10305815,PJN_wiecej_godzin_historii_w_szkolach.html, 28.08.2012 r.

${ }^{2}$ Ustawa $\mathrm{z}$ dnia 7 września 1991 r. o systemie oświaty, Dz. U. 1991, Nr 95, poz. 425.

3 A. Wolff-Powęska, Pamięć - brzemię i uwolnienie. Niemcy wobec nazistowskiej przeszłości (1945-2010), Poznań 2010, s. 67-68.

${ }^{4}$ Przebieg dyskusji o nadanie określonych i jednoznacznych treści poszczególnym terminom powiązanym z zagadnieniem, czy w ogóle wyjaśnienie danych kategorii i terminów, a więc m.in. polityki historycznej, historii drugie-
} 
wić przyczynek do szerszych rozważań o polityce historycznej państwa, jej potencjale jako źródle konfliktu politycznego, czy wreszcie jej wpływie na tożsamość społeczeństwa, charakter pamięci zbiorowej.

Reforma modyfikuje nauczanie historii przede wszystkim poprzez implementację treści dwóch dokumentów: Rozporządzenia Ministra Edukacji Narodowej z dnia 7 lutego 2012 r. w sprawie ramowych planów nauczania w szkołach publicznych (Dz. U. 2012, Nr 0, poz. 204) oraz Rozporządzenia Ministra Edukacji Narodowej z dnia 23 grudnia 2008 r. w sprawie podstawy programowej wychowania przedszkolnego oraz kształcenia ogólnego w poszczególnych typach szkół (Dz. U. 2009, Nr 4, poz. 17). W oparciu o nie, uczniowie zamiast dotychczas realizowanych dwóch pełnych cykli kształcenia historycznego (zarówno w gimnazjum, jak i w liceum omawiany był materiał od najdawniejszych dziejów człowieka i starożytności do czasów współczesnych), w III etapie edukacyjnym (gimnazjum) zrealizują materiał do zakończenia I wojny światowej, a w IV etapie edukacyjnym (zasadnicza szkoła zawodowa, liceum ogólnokształcące, technikum) będą uczyć się historii Polski i świata po 1918 r. $^{5}$

Zmianie ulegnie także liczba godzin przeznaczona na nauczanie historii. W oparciu o Rozporządzenie Ministra Edukacji Narodowej i Sportu z dnia 12 lutego 2002 r. w sprawie ramowych planów nauczania w szkołach publicznych (Dz. U. 2002, Nr 15, poz. 142) wynosiła ona dla III etapu edukacji 6 godzin tygodniowo w trzyletnim okresie nauczania, a dla IV etapu edukacji 5 godzin. Reforma w sposób zasadniczy zmienia nie tylko liczbę tych godzin, ale również sposób ich obliczania. Dotychczas ustawodawca określał minimalną ogólną liczbę godzin przeznaczoną na poszczególne obowiązkowe zajęcia edukacyjne, obliczone na 32-tygodniowe lata szkolne ${ }^{6}$ lub 30-tygodniowe lata szkolne ${ }^{7}$. Rozwiązanie to było o tyle problematyczne, że w każdym roku szkolnym liczba tygodni nauki jest zmienna (choć uśredniając wynosi 35-36 tygodni) i pozostałe 3-6 tygodni, dyrektor szkoły przeznaczał albo na kontynuowanie obowiązkowych zajęć edukacyjnych realizowanych w systemie klasowo-lekcyjnym bądź w innej formie. Regulacje obowiązujące w następstwie ostatniej reformy oświaty, zakładają określenie minimalnej ogólnej liczby godzin przeznaczonych na realizację podstawy programowej kształcenia ogólnego z poszczególnych obowiązkowych zajęć edukacyjnych $\mathrm{w}$ całym okresie nauczania danego etapu edukacyjnego ${ }^{8}$.

Trzecią - najistotniejszą zmianą jest wprowadzenie zróżnicowanego nauczania przedmiotów w zakresie podstawowym i rozszerzonym w okresie IV etapu edukacyjnego, po ukończeniu przez ucznia pierwszej klasy. Zyskując możliwość realizacji określonych przedmiotów w formie rozszerzonej (z kanonu przedmiotów matematyczno-przyrodniczych lub humanistycznych), ma on jednocześnie obowiązek uczęszczania na lekcje przedmiotu uzupełniającego historia i spoleczeństwo (w wymiarze 120 godzin - gdy zdecyduje się na realizację

go stopnia, świadomości historycznej, pamięci zbiorowej, pamięci zbiorowej najwyższego poznania, pamięci społecznej, pamięci indywidualnej, pamięci społeczno-komunikatywnej, pamięci kulturowo-instytucjonalnej i wielu innych, odnaleźć można w pracach m.in. A. Assmann, J. Assmanna, B. Baczko, M. Golki, M. Halbwachsa, L. Nijakowskiego, P. Nora, P. Ricouer, B. Szackiej, R. Traby, A. Wolff-Powęskiej.

${ }^{5}$ Portal edukacyjny Perspektywy.pl, W szkołach ponadgimnazjalnych od września po nowemu, http://www.perspektywy.pl/index.php?option=com_content\&task=view\&id=4802\&Itemid=106, 28.08.2012 r.

${ }^{6}$ Obowiązkowe zajęcia edukacyjne w szkole podstawowej, gimnazjum, zasadniczej szkole zawodowej, klasie wstępnej liceum ogólnokształcącego z oddziałami dwujęzycznymi i szkole policealnej.

${ }^{7} \mathrm{~W}$ pozostałych - innych niż szkoła podstawowa, gimnazjum, zasadnicza szkoła zawodowa, klasa wstępna liceum ogólnokształcącego z oddziałami dwujęzycznymi i szkoła policealna - typach szkół ponadgimnazjalnych.

${ }^{8}$ Portal edukacyjny Perspektywy.pl, W szkołach ponadgimnazjalnych od września po nowemu, http://www.perspektywy.pl/index.php?option=com_content\&task=view\&id=4802\&Itemid=106, 28.08.2012 r. 
kanonu przedmiotów matematyczno-przyrodniczych w formie rozszerzonej), lub 240 godzin (przedmiot historia) - gdy zdecyduje się na realizację kanonu przedmiotów humanistycznych w formie rozszerzonej ${ }^{9}$. Wymiar godzinowy nauczania przedmiotu historia oraz historia i społeczeństwo w zakresie podstawowym i rozszerzonym w okresie IV etapu edukacyjnego prezentuje tabela 1 .

Wymiar godzinowy nauczania przedmiotu historia oraz historia $i$ spoleczeństwo

Tabela 1 w zakresie podstawowym i rozszerzonym w okresie IV etapu edukacyjnego

\begin{tabular}{||l|c|c||}
\hline \hline & $\begin{array}{c}\text { I klasa } \\
\text { IV etapu edukacji }\end{array}$ & $\begin{array}{c}\text { II i III klasa } \\
\text { IV etapu edukacji }\end{array}$ \\
\hline $\begin{array}{l}\text { Liczba godzin obowiązkowych zajęć edukacyjnych, } \\
\text { w przypadku realizacji przedmiotów humanistycznych } \\
\text { w zakresie podstawowym }\end{array}$ & $\begin{array}{c}60 \text { godzin } \\
\text { (przedmiot historia) }\end{array}$ & $\begin{array}{c}120 \text { godzin } \\
\text { (przedmiot historia } \\
\text { i społeczeństwo) }\end{array}$ \\
\hline $\begin{array}{l}\text { Liczba godzin obowiązkowych zajęć edukacyjnych, } \\
\text { w przypadku realizacji przedmiotów humanistycznych } \\
\text { w zakresie rozszerzonym }\end{array}$ & $\begin{array}{c}60 \text { godzin } \\
\text { (przedmiot historia) }\end{array}$ & $\begin{array}{c}240 \text { godzin } \\
\text { (przedmiot historia) }\end{array}$ \\
\hline $\begin{array}{l}\text { Liczba godzin obowiązkowych zajęć edukacyjnych } \\
\text { z przedmiotu historia (przed wprowadzeniem reformy } \\
\text { oświaty) }\end{array}$ & $\begin{array}{c}\text { Liczba godzin tygodniowo w trzyletnim okresie } \\
\text { nauczania }\end{array}$ \\
\hline \hline
\end{tabular}

* Ustawodawca przed reformą określał minimalną ogólną liczbę godzin przeznaczonych na poszczególne obowiązkowe zajęcia edukacyjne, obliczoną na 30-tygodniowe lata szkolne.

Źródło: Opracowanie własne na podstawie Rozporządzenia Ministra Edukacji Narodowej i Sportu z dnia 12 lutego 2002 r. $w$ sprawie ramowych planów nauczania w szkołach publicznych (Dz. U. 2002, Nr 15, poz. 142) oraz Rozporządzenie Ministra Edukacji Narodowej z dnia 7 lutego 2012 r. w sprawie ramowych planów nauczania w szkołach publicznych (Dz. U. 2012, poz. 204).

Poza tym, warto nadmienić, że wymiar godzinowy nauczania przedmiotu historia i społeczeństwo w II etapie edukacyjnym wynosił przed reformą 128 godzin, po reformie - 130 godzin. W III etapie wymiar godzinowy nauczania przedmiotu historia wynosił przed reformą 192 godziny, po reformie - 190 godzin.

Ostatnią kwestia, niezbędną dla wprowadzenia do zagadnienia, jest krótkie omówienie treści przedmiotu historia i społeczeństwo (dla IV etapu edukacji). Cytując komentarz do podstawy programowej, stworzony przez MEN, jest to przedmiot uzupełniający (choć obowiązkowy), którego celem jest poszerzenie wiedzy z zakresu historii z elementami wiedzy o społeczeństwie $i$ wiedzy o kulturze ${ }^{10}$. Na zajęciach tych nauczyciel może realizować badź watek tematyczny, czyli omówić wybrany temat we wszystkich epokach historycznych, badź watek epokowy, czyli omówić wszystkie tematy w zakresie wybranej epoki

\footnotetext{
${ }^{9}$ Rozporządzenie Ministra Edukacji Narodowej z dnia 23 grudnia 2008 r. w sprawie podstawy programowej wychowania przedszkolnego oraz ksztatcenia ogólnego w poszczególnych typach szkół (Dz. U. 2009, Nr 4, poz. 17), załącznik nr 4 - Podstawa programowa kształcenia ogólnego dla gimnazjów i szkót ponadgimnazjalnych, których ukończenie umożliwia uzyskanie świadectwa dojrzałości po zdaniu egzaminu maturalnego.

${ }^{10}$ Ministerstwo Edukacji Narodowej, Podstawa programowa z komentarzami, t. 4: Edukacja historyczna i obywatelska w szkole podstawowej, gimnazjum i liceum historia i społeczeństwo, historia, wiedza o społeczeństwie, podstawy przedsiębiorczości, ekonomia $w$ praktyce, wychowanie do życia $w$ rodzinie, etyka, filozofia, s. 60, http://www.men.gov.pl/index.php?option=com_content\&view=article\&id=2060\%3Atom-4-edukacja-historyczna-i-obywatelska-w-szkole-podstawowej-gimnazjum-i-liceum-\&catid=230\%3Aksztacenie-i-kadra-ksztacenie-ogolne-podstawa-programowa\&Itemid=290, 28.08.2012 r.
} 
historycznej ${ }^{11}$. Wątki (moduły) są następujące: „Europa i świat”, „Język, komunikacja i media”, „Kobieta i mężczyzna, rodzina”, „Nauka”, „Swojskość i obcość”, „Gospodarka”, „Rządzący i rządzeni”, „Wojna i wojskowość”, „Ojczysty Panteon i ojczyste spory”. Nauczyciel ma obowiązek zrealizować co najmniej cztery moduły (np. cztery wątki tematyczne lub dwa wątki tematyczne i dwa wątki epokowe) ${ }^{12}$. Wszystkie powyższe mają stanowić rozwinięcie i uzupełnienie wiedzy ucznia zdobytej w okresie III etapu edukacji oraz I klasy IV etapu edukacji ${ }^{13}$.

Według podanych przez MEN informacji założenia reformy programowej były znane opinii publicznej już w 2008 r., a sama reforma stała się przedmiotem szerokich konsultacji (ponad 2,5 tys. opinii i uwag oraz ponad 200 recenzji sporządzonych przez ekspertów, pozytywne stanowiska Konferencji Rektorów Akademickich Szkół Polskich, Rady Głównej Szkolnictwa Wyższego, Prezydium Państwowej Komisji Akredytacyjnej, a także Polskiego Towarzystwa Historycznego ${ }^{14}$. Ponadto stanowiła odpowiedź na postulat środowisk nauczycielskich, które zwracały uwagę na niemożność realizacji zagadnień obejmujących współczesność (szczególnie po roku 1945), ze względu na powtarzalność cyklu nauczania, a więc rozpoczynanie, zarówno III, jak i IV etapu edukacyjnego od czasów najdawniejszych, starożytnych.

Powyżej nakreślone zmiany, stały się osią konfliktu politycznego, przyczyną licznych akcji społecznych, w tym największej „Przywracamy lekcje historii do szkół!”, której zadaniem, według jej inicjatorów, jest zintegrowanie wokót ważnej sprawy, będacej polska racja sta$n u !^{15}$. Pomysłodawcy akcji utrzymują, że sednem reformy edukacyjnej MEN jest pozbawienie nauczania historii chronologii, bardzo wybiórcze jej potraktowanie i poddanie możliwościom ogromnych manipulacji, a polski rzad wyrzuca z liceów obowiqzkowe lekcje historii ${ }^{16}$. Prezentuja przy tym wyliczenia liczby godzin historii nauczanych przed i po wprowadzeniu reformy oraz związane z tym postulaty. Informują więc, że przed reformą w II etapie edukacyjnym nauczano przedmiotu historia i spoleczeństwo w liczbie 130 godzin (zastosowany został więc przelicznik 32,5-tygodniowego roku szkolnego - choć ustawodawca określił go na 32-tygodniowy rok szkolny) i zwracają uwagę, że choć reforma zakłada w teorii tę sama liczbe godzin [...], ale poprzez likwidacje 9-ciu tzw. godzin dyrektorskich w praktyce ogranicza dotychczasowa ilość lekcji historii, gdyż dyrektorzy z reguły dodatkowa godzine dodawali na lekcje historii ${ }^{17}$. Ponadto inicjatorzy akcji utrzymuja, że nowa podstawa programowa pomija chrzest Polski. Faktycznie, literalnie nie jest on ujęty w komentarzu ministerialnym do podstawy programowej, jednakże znajduje się tam podpunkt uczeń opowiada historię zjazdu gnieźnieńskiego, uwzględniajac postacie: św. Wojciecha, Bolesława Chrobrego i Ottona III, stąd można domniemywać, że wobec powyższego niemożliwym byłoby nie wspomnienie

\footnotetext{
${ }^{11}$ Ibidem.

${ }^{12}$ Ibidem.

${ }^{13}$ Dla przykładu, w oparciu o uzyskaną wcześniej faktograficzną wiedzę uczeń w ramach modułu ,Swojskość i obcość” analizuje wielokulturowość społeczeństwa II RP, a realizując moduł „Gospodarka” charakteryzuje gospodarkę kapitalistyczną w XIX w.; opisuje miasto przemysłowe, wyjaśnia główne założenie marksowskiej teorii ekonomicznej - Ministerstwo Edukacji Narodowej, Podstawa programowa z komentarzami, t. 4..., op. cit.

${ }^{14}$ Newsweek.pl, Kaczyński: Ograniczenie nauki historii to postkolonializm, http://m.newsweek.pl/polska,kaczynski--ograniczenie-nauki-historii-to-postkolonializm,90141,3,1.html, 28.08.2012 r.

${ }_{16}$ Przywracamy lekcje historii do szkót!, O akcji, http://www.przywracamyhistorie.pl/o-akcji.html, 28.08.2012 r.

${ }^{16}$ Ibidem.

${ }^{17}$ Ibidem
} 
przez nauczyciela o chrzcie Polski, będącym warunkiem zaistnienia wymienionych faktów historycznych.

Do przebiegu III etapu edukacyjnego w zakresie nauczania przedmiotu historia i społeczeństwo, inicjatorzy akcji nie mają zastrzeżeń. Tych przedstawili najwięcej w odniesieniu do IV etapu edukacyjnego. Utrzymują oni, że po reformie nauczanie przedmiotu historia będzie się odbywać dla pierwszych klas IV etapu edukacyjnego: niehumanistycznych w wymiarze 30 godzin i 60 godzin dla klas humanistycznych (co jest sprzeczne z treścią Załącznika nr 7 do Rozporządzenia Ministra Edukacji Narodowej z dnia 7 lutego 2012 r. w sprawie ramowych planów nauczania w szkołach publicznych (Dz. U. 2012, poz. 204), który zakłada jednakową liczbę - 60 godzin dla obu zakresów nauczania, potwierdza to także odpowiedź podsekretarza stanu w Ministerstwie Edukacji Narodowej - z upoważnienia ministra - na interpelację nr $5150 \mathrm{w}$ sprawie projektu nowego modelu szkolnictwa ponadgimnazjalnego ${ }^{18}$ ).

Postulatami inicjatorów akcji są: pozostawienie w całym trzyletnim okresie w liceach i technikach nauczania w ramach przedmiotu historia, tj. po 2 godz. tygodniowo wraz ze zwiększeniem liczby godzin nauczania przedmiotu do 180 godzin, tj. o 30 godzin względem liczby godzin sprzed reformy oraz zwiększenia liczby godzin nauczania przedmiotu historia $i$ społeczeństwo do 165 godz. (tj. o 35 godzin) w klasach IV-VI szkoły podstawowej ${ }^{19}$. Ponadto nauczanie tych przedmiotów ma charakteryzować chronologiczne przedstawianie faktów, a nie ujęcie problematyczne danego zagadnienia w oparciu o posiadaną przez ucznia wiedzę z poprzedniego etapu edukacyjnego.

Członkami komitetu honorowego akcji są w dużej części osoby związane ze Stowarzyszeniem Klubu Inteligencji Polskiej (aż pięciu członków), następnie z zespołem wspierania Radia Maryja i związanego z tą rozgłośnią stowarzyszenia „Nasza przyszłość Polska”, „Solidarnością", Honorowym Komitetem Poparcia Lecha Kaczyńskiego w wyborach prezydenckich w roku 2005 r., „Gazetą Polską”, Stowarzyszeniem Młodzież Wszechpolska. Ponadto komitet honor tworzy prezes SKOK, założyciel „Nowego Ekranu” - Niezależnego serwisu społeczności blogerów, dziennikarze: Łukasz Warzecha, Bronisław Wildstein, Rafał A. Ziemkiewicz oraz inni szerzej znani naukowcy, artyści, działacze: prof. Zdzisław Krasnodębski, dr hab. Sławomir Cenckiewicz, ks. Tadeusz Isakowicz-Zaleski, Paweł Kukiz, Zuzanna Kurtyka ${ }^{20}$. Akcję wspierają kluby „Gazety Polskiej” z terenu całego kraju, Stowarzyszenie Solidarni 2010, Pomnik Smoleński, Stowarzyszenie Marsz Niepodległości, liczne fundacje (np. „Polska się Upomni”, „Niepodległości”) i stowarzyszenia (np. „Patriotyczne Sympatyków płk Ryszarda Kuklińskiego”, „Robotników Chrześcijańskich”, „Kibiców Wisły Kraków”) ${ }^{21}$. Akcja posiada także radę naukową składającą się z ponad dwudziestu przedstawicieli szkolnictwa wyższego, w dużej mierze reprezentujących środowisko krakowskie, a szczególnie Instytut Historii Uniwersytetu Jagiellońskiego ${ }^{22}$.

\footnotetext{
${ }^{18}$ Sejm Rzeczypospolitej Polskiej, Odpowiedź podsekretarza stanu w Ministerstwie Edukacji Narodowej - z upoważnienia ministra - na interpelację $\mathrm{nr} 5150 \mathrm{w}$ sprawie projektu nowego modelu szkolnictwa ponadgimnazjalnego, http://www.sejm.gov.pl/sejm7.nsf/InterpelacjaTresc.xsp?key=50FC74A1, 28.08.2012 r.

${ }^{19}$ Przywracamy lekcje historii do szkół!, O akcji, http://www.przywracamyhistorie.pl/o-akcji.html, 28.08.2012 r.

${ }^{20}$ Przywracamy lekcje historii do szkót!, Komitet honorowy, http://www.przywracamyhistorie.pl/komitet-honorowy.html, 28.08.2012 r.

${ }^{21}$ Przywracamy lekcje historii do szkót!, Wspieraja akcje, http://www.przywracamyhistorie.pl/wspieraja-akcje.html, 28.08.2012 r.

${ }^{22}$ Przywracamy lekcje historii do szkót!, Rada naukowa, http://www.przywracamyhistorie.pl/rada-naukowa.html, 28.08.2012 r.
} 
Akcja „Przywracamy lekcje historii do szkół!” została zainaugurowana w całej Polsce w dniu 2 maja - dniu Flagi Rzeczypospolitej - poprzez zbieranie podpisów pod projektem ustawy o zmianie ustawy o systemie oświaty, stworzonym przez inicjatorów akcji (zawiera wyżej omówione postulaty) ${ }^{23}$. Jak wówczas zakładali działacze Solidarnej Polski, intensywnie zaangażowani w akcję, zebranie 100 tys. podpisów powinno się zakończyć w lipcu ${ }^{24}$. Poprzedziły ją jeszcze głodówki w obronie nauczania historii, prowadzone m.in. przez opozycjonistów z okresu PRL, historyków IPN, radnego PiS. Miały one miejsce w kilku miastach Polski (Kraków, Warszawa, Wrocław, Siedlce, Tarnowskie Góry, Częstochowa) ${ }^{25}$. Kolejnym, chronologicznie rzecz ujmując wydarzeniem, było złożenie przez PiS wniosku o wotum nieufności wobec minister Szumilas (w uzasadnieniu zawierał więcej zarzutów niż tylko kształt reformy nauczania historii) ${ }^{26}$, który nie uzyskał poparcia wymaganej większości głosów (za odwołaniem opowiedziały się kluby: PiS, Solidarna Polska i Ruch Palikota) ${ }^{27}$. Zanim jednak doszło do głosowania, odbył się Kongres Organizacyjny Obywatelskiej Komisji Edukacji Narodowej, nad którym merytoryczny patronat objął Instytut Historii Uniwersytetu Jagiellońskiego $^{28}$. Podjęta na nim uchwała, nawiązywała do spotkania mającego miejsce w Pałacu Prezydenckim w kwietniu 2012 r. ${ }^{29}$, w którym udział wzięli Prezydent RP, Minister Edukacji K. Szumilas oraz zwolennicy i krytycy reformy. W treści uchwały z całą stanowczością podkreślano, iż postulat o obowiązkowym charakterze nauczania modułu „Ojczysty Panteon i ojczyste spory" w podwojonej liczbie godzin [nie 30, jak zakłada rozporządzenie ministerialne w odniesieniu do jakiegokolwiek wybranego modułu, a 60 - przyp. aut. J.K.] ma charakter minimalny i nienegocjowalny ${ }^{30}$. Kompromisowe stanowisko minister Szumilas, będące odpowiedzią na powyższe, zakładało jedynie, że każdy podręcznik przeznaczony do nauczania przedmiotu , historia i społeczeństwo” na IV etapie edukacyjnym będzie musiat obowiazkowo obejmować treści z zakresu watku tematycznego „, Ojczysty Panteon i ojczyste spory”. Obecność treści tego watku w każdym podręczniku do historii i społeczeństwa, z pew-

${ }^{23}$ Przywracamy lekcje historii do szkót!, Projekt ustawy, http://www.przywracamyhistorie.pl/projekt-ustawy.html, 28.08.2012 r.

${ }^{24}$ Onet.pl Wiadomości, 2 maja ruszy akcja „Przywracamy lekcje historii”, http://wiadomosci.onet.pl/regionalne/opole/2-maja-ruszy-akcja-przywracamy-lekcje-historii,1,5119288,region-wiadomosc.html, 28.08.2012 r.

${ }^{25}$ Jej zapoczątkowanie miało miejsce w marcu 2012 r., kiedy pięciu działaczy opozycyjnych z okresu PRL rozpoczęło w kościele św. Stanisława Kostki w Krakowie głodówkę przeciwko zmianom w programach nauczania w szkołach - niezelazna.pl my informujemy - oni kłamią, Głoduja w obronie lekcji historii, http://niezalezna.pl/25450-gloduja-w-obronie-lekcji-historii, 28.08.2012 r. oraz w Warszawa - Polskie Radio.pl, Warszawa: trwa głodówka w ,obronie” historii, http://www.polskieradio.pl/5/3/Artykul/577304,Warszawa-trwa-glodowka-w-obronie-historii, 28.08.2012 r. Pozostałe miasta, w których podjęto głodówki wyszczególnione zostały w artykule Głoduja w obronie polskiej szkoły, bo takie będq Rzeczypospolite, jakie ich młodzieży chowanie, NWONEWS.PL, http://nwonews.pl/artykul,3546, Gloduja-w-obronie-polskiej-szkoly-bo-takie-beda-Rzeczypospolite-jakie-ich-mlodziezy-chowanie, 28.08.2012 r.

${ }^{26}$ Prawo i Sprawiedliwość, PiS złoży wniosek o wotum nieufności wobec minister Szumilas, http://www.pis. org.pl/article.php?id=20227, 28.08.2012 r.

${ }^{27}$ Onet.pl Wiadomości, Sejm odrzucit wniosek o odwołanie minister edukacji, http://wiadomosci.onet.pl/ kraj/sejm-odrzucil-wniosek-o-odwolanie-ministeredukacj,1,5141605,wiadomosc.html, $28.08 .2012 \mathrm{r}$.

${ }^{28}$ Interia.pl Fakty, Głodówka, okupacja i kongres, http://fakty.interia.pl/polska/news/glodowka-okupacja-i-kongres, 1797833, 28.08.2012 r.

${ }^{29}$ dzieje.pl portal historyczny, W Pałacu Prezydenckim odbędzie się debata o reformie nauczania historii, http://dzieje.pl/aktualnosci/w-palacu-prezydenckim-odbedzie-sie-debata-o-reformie-nauczania-historii, 28.08.2012 r.

${ }^{30}$ wPolityce.pl codziennie ważne informacje ze świata polityki, Obywatelska Komisja Edukacji Narodowej powołana. Będzie patrzeć władzy na ręce w sprawach edukacji - bo patrzeć trzeba, http://wpolityce.pl/dzienniki/jeden-taki/28886-obywatelska-komisja-edukacji-narodowej-powolana-bedzie-patrzec-wladzy-na-rece-w-sprawach-edukacji-bo-patrzec-trzeba, 28.08.2012 r. 
nościq wzmocni, zawarte w podstawie programowej, zalecenie realizowania go przez wszystkich uczniów ${ }^{31}$. Krytycy reformy nie uznali tego stanowiska za satysfakcjonujące, część z nich domagała się ponadto uznania za również obowiązkowy - moduł „Rządzący i rządzeni" ${ }^{32}$. Kolejnym działaniem podjętym przez przeciwników reformy było powołanie w dniach 1-3 czerwca 2012 r., przez uczestników głodówek, Stowarzyszenia Ruch Edukacji Narodo$w^{33}$. Trudno ocenić, czy ten kolejny oddolny ruch stał się przyczyną, zmiany decyzji Minister Edukacji. Niemniej 12 czerwca 2012 r. wydano uzupełnienie do rozporządzenia, w którym zawarto informację, iż moduł „Ojczysty Panteon i ojczyste spory” stanie się obowiązkowy ${ }^{34}$. Przeciwnicy reformy uznali ten kompromis za minimalistyczny i tymczasowy, podkreślając że celem jest powrót do normalnego nauczania historii ${ }^{35}$. Niejako podkreśleniem faktu nieodstąpienia od dalszych działań, było oświadczenie Obywatelskiej Komisji Edukacji Narodowej, dotyczące wyboru podręczników do nauczania historii. Stwierdziła ona, że wszystkie, dopuszczone do użytku szkolnego przez MEN podręczniki, zawieraja błędy wymagajace wprowadzenia poważnych korekt, jednak w zaistniałej sytuacji [presja czasowa wynikająca z konieczności podania do wiadomości publicznej przez dyrektorów liceów listy podręczników - przyp. aut. J.K.], zdecydowano o rekomendacji dwóch ${ }^{36}$.

Wszystkie powyżej opisane działania poszczególnych organizacji społecznych, czy partii politycznych, stanowią niezbędne ramy do analizy dyskursu publicznego. Retoryka - charakter wypowiedzi, dobór słownictwa, przywoływanie odpowiednich skojarzeń - stosowana przez poszczególnych nadawców, zwłaszcza krytyków reformy (strona najbardziej aktywna) stanowi niewątpliwie interesujący przedmiot badań. Dalsza część artykułu zostanie poświęcona właśnie temu zagadnieniu.

Analizę warto rozpocząć od przywołania treści oficjalnych komunikatów inicjatorów akcji „Przywracamy lekcje historii do szkół!”. Jako cel reformy oświaty określili oni pozbawienie nauczania historii chronologii, bardzo wybiórcze jej potraktowanie i poddanie możliwościom ogromnych manipulacji oraz stwierdzili, że polski rzqd [...] wyrzuca z liceów obowiazkowe

${ }^{31}$ wPolityce.pl codziennie ważne informacje ze świata polityki, List minister Krystyny Szumilas. Szefowa MEN popiera kompromis $w$ sprawie lekcji historii $w$ liceach, ale... go nie wcieli $w$ życie, http://wpolityce.pl/wydarzenia/28804-list-minister-krystyny-szumilas-szefowa-men-popiera-kompromis-w-sprawie-lekcji-historii-w-liceach-ale-go-nie-wcieli-w-zycie, 28.08.2012 r.

${ }^{32}$ P. Zaręba, Promyk nadziei jest. Ale walka o historię trwa. Relacja Piotra Zaremby po ,okragtym stole historyków" u prezydenta, Polityce.pl codziennie ważne informacje ze świata polityki, http://wpolityce.pl/dzienniki/jeden-taki/26761-promyk-nadziei-jest-ale-walka-o-historie-trwa-relacja-piotra-zaremby-po-okraglym-stole-historykow-u-prezydenta, 28.08.2012 r.

${ }^{33}$ wPolityce.pl codziennie ważne informacje ze świata polityki, Uczestnicy głodówek w obronie polskiej szkoły powołali RUCH EDUKACJI NARODOWEJ, http://wpolityce.pl/wydarzenia/29798-uczestnicy-glodowek-w-obronie-polskiej-szkoly-powolali-ruch-edukacji-narodowej, 28.08.2012 r.

${ }^{34}$ Uzasadnienie do projektu rozporzqdzenia stanowiacego wykonanie upoważnienia zawartego w art. 22 ust. 2 pkt 2 lit. a i b ustawy z dnia 7 września 1991 r. o systemie oświaty (Dz. U. 2004, Nr 256, poz. 2572, z późn. zm.), w brzmieniu nadanym ustawą z dnia 19 sierpnia 2011 r. o zmianie ustawy o systemie oświaty oraz niektórych innych ustaw (Dz. U. Nr 205, poz. 1206), http://www.men.gov.pl/images/stories/pdf1/Uzasadnienie_projektu.pdf, 28.08.2012 r.

${ }^{35}$ wPolityce.pl codziennie ważne informacje ze świata polityki, Zaremba po decyzji Szumilas: To cieszy, ale to mniejsze zło. „Prawdziwym celem jest powrót do normalnego nauczania historii”, http://wpolityce.pl/wydarzenia/30322-zaremba-po-decyzji-szumilas-to-cieszy-ale-to-mniejsze-zlo-prawdziwym-celem-jest-powrot-do-normalnego-nauczania-historii, 28.08.2012 r.

${ }^{36}$ wPolityce.pl codziennie ważne informacje ze świata polityki, Przekażcie nauczycielom - to ostatnie dni na decyzję. Obywatelska KEN radzi w sprawie wyboru podręcznika do historii, http://wpolityce.pl/wydarzenia/ 30321-przekazcie-nauczycielom-to-ostatnie-dni-na-decyzje-obywatelska-ken-radzi-w-sprawie-wyboru-podrecznika-do-historii, 28.08.2012 r. 
lekcje historii [...] zamiast tego proponuje się dziwaczne połaczenie lekcji WOS-u, przysposobienia obronnego oraz historii o nazwie historia i społeczeństwo. W następstwie młodzi Polacy zamiast wiedzy o Powstaniu Warszawskim będa się uczyć modułu: kobieta i mężczyzna, rodzina, albo zamiast wiedzy o Żotnierzach Wyklętych mogq natrafić na modut swojskość i obcość, badź też zamiast wiedzy o wielkim zwycięstwie rodaków $w$ wojnie polsko-bolszewickiej natrafiq na modut język, komunikacja i media. Konkludując, zwrócili się z apelem, w którym oświadczyli, że Musimy, bez względu na dzielace nas różnice, zintegrować się wokót ważnej sprawy, będacej polska racja stanu! Pokażmy, że jest nas tysiace i nie damy wyjałowić polskości z naszej młodzieży oraz budowanie poczucia wspólnoty i więzi pomiędzy rodakami może odbywać się tylko poprzez znajomość polskiej historii ${ }^{37}$.

Kolejne, nacechowane dużym stopniem emocjonalności sformułowania, znaleźć można w projekcie ustawy o zmianie ustawy o systemie oświaty, stworzonym przez inicjatorów powyższej akcji. Mowa tutaj o: taki stan rzeczy wskazuje na odejście od ksztattowania postaw młodych Polaków w oparciu o wspaniałe wzorce znane z naszej historii [...], czy rugowanie i ograniczanie lekcji historii pokazuje, jak bardzo zaburzyliśmy hierarchię wartości i poczucie odpowiedzialności za budowanie polskiej wspólnoty narodowej, rozumianej jako ciagłość nie tylko pokoleń, wartości, ale również państwa ${ }^{38}$. Według autorów projektu jego realizacja może ten stan jeszcze zmienić, a więc umożliwić pozyskanie przez państwo polskie sprzymierzeńca w walce o budowanie wspólnoty narodowej w postaci kolejnych pokoleń uksztaltowanych w poczuciu odpowiedzialności za Ojczyznę $e^{39}$.

Poza oficjalnymi komunikatami, często na temat reformy wypowiadali się członkowie komitetu honorowego, rady naukowej akcji, czy po prostu jej sympatycy. Redaktor Łukasz Warzecha oświadczył, że intencjami autorów reformy mogło być wypchnięcie [uczniów - przyp. red. J.K.] w kierunku kształcenia do zawodu ze względu na czynniki demograficzne. Po to, żeby oni się dtużej nie wahali, żeby mieli bardzo ograniczony wybór na etapie studiów, żeby nie była możliwa łatwa zmiana na etapie kierunku studiów ${ }^{40}$. Profesor Andrzej Nowak, główny mówca podczas „okrągłego stołu” w Pałacu Prezydenckim, autor pomysłu o obligatoryjnym charakterze modułu „Ojczysty Panteon i ojczyste spory” twierdzi, iż reforma dzieli społeczeństwo na tych z poprzedniego pokolenia, którzy mieli jednq wspólna edukację historycznq i na tych z nowego pokolenia - po reformie minister Hall, tym samym Polacy w wieku 17, 18 lat straca wspólnq oś historycznej świadomości, wokół której można dyskutować o sprawach polskich w Europie ${ }^{41}$. Ponadto zwrócił on uwagę, że choć kryzys tożsamości historycznej ma wymiar ogólnocywilazycjny i nie wymyślit go rząd Donalda Tuska, to jeżeli ta tendencja nie zostania zahamowana pojawi się anomia społeczna i nastapi przesuwanie się świata albo w stronę chaosu albo w stronę totalitaryzmu, jako odpowiedzi na $\operatorname{chaos}^{42}$. Z kolei

\footnotetext{
${ }^{37}$ Przywracamy lekcje historii do szkót!, O akcji, http://www.przywracamyhistorie.pl/o-akcji.html, 28.08.2012 r.

${ }^{38}$ Przywracamy lekcje historii do szkót!, Projekt ustawy, http://www.przywracamyhistorie.pl/projekt-ustawy.html, 28.08.2012 r.

${ }^{39}$ Ibidem.

${ }^{40}$ Gazeta.pl, Rusza akcja „Przywracamy lekcje historii”. „Polak może nie wiedzieć, co to pantofelek, ale nie może nie znać historii", http://wiadomosci.gazeta.pl/wiadomosci/1,114883,11650731,Rusza_akcja_Przywracamy_lekcje_historii__Polak.html, 28.08.2012 r.

${ }^{4} 1$ ARCANA, Bez mądrej edukacji będziemy skazani na rozpad naszej wspólnoty - od kryzysu edukacji do kryzysu cywilizacji. Rozmowa z profesorem Andrzejem Nowakiem. Część I, http://www.portal.arcana.pl/Bez-madrej-edukacji-bedziemy-skazani-na-rozpad-naszej-wspolnoty-od-kryzysu-edukacji-do-kryzysu-cywilizacji-rozmowa-z-profesorem-andrzejem-nowakiem-czesc-i,2881.html, 28.08.2012 r.

42 Ibidem
} 
Krzysztof Skowroński, szef Stowarzyszenia Dziennikarzy Polskich reformę oświaty utożsamił z tworzeniem nowego człowieka - osobnika bez świadomości historycznej, niereligijnego, niezwiqzanego z rodzina, swoim krajem, narodem. Takiego idealnego indywidualistę bez korzeni, źródła. Jego wolność jest oczywiście złudna i pozorna, bo w rzeczywistości ktoś, kto nie ma hierarchii wartości, dla którego wszystko jest względne, to bezwolna ofiara manipulacji. Nie ma na czym się oprzeć, do czego się odwołać. Myśli to, co mówiq mu media. Powtarza brukselskie modlitwy i przekazy dnia ${ }^{43}$.

Kolejną grupę krytyków reformy stanowili przedstawiciele Solidarnej Polski oraz Prawa i Sprawiedliwości. Prezes tej ostatniej partii - Jarosław Kaczyński - oznajmił, że zmiany w edukacji mają postkolonialny charakter, a ograniczenie ilości lekcji historii w szkołach może sprawić, że Polacy zamieniq się po prostu $w$ taniq siłę robocza dla bogatszych od nas ${ }^{44}$. Tym samym staną się oni zasobem dla chwiejacego się systemu Europy zachodniej. Zasobem, z którego czerpie się zyski, taniq siłę roboczq $i$ to, czego samemu się już nie ma ${ }^{45}$. Marzena Machałek, posłanka PiS, zasugerowała, że reforma oświaty to demontaż polskiego państwa przez demontaż polskiej edukacji oraz zapytała jakiego człowieka ma ukształtować polska szkoła? Czy ma ukształtować niezbyt wybrednego konsumenta ponadnarodowych koncernów, czy taniq siłę roboczq, bo właśnie tak należy oceniać cel wprowadzenia takiej podstawy programowej $^{46}$. Jej partyjny kolega, Mariusz Błaszczak dodał, że MEN działa sprzecznie z maksymą Alberta Einsteina, i przytoczył słowa fizyka, odnosząc je do absolwenta liceum. Ma on posiadać harmonijnq osobowość, a nie być specjalista ${ }^{47}$.

Głos w sprawie reformy oświaty zabierali także przedstawiciele Kościoła katolickiego. Arcybiskup Józef Michalik w kazaniu rezurekcyjnym określił zmiany w obszarze edukacji publicznej krótkim sformułowaniem to jest dramat ${ }^{48}$. W podobnym tonie wypowiedział się biskupi kielecki Kazimierz Ryczan, który podczas homilii wygłoszonej w dniu Święta Konstytucji 3 Maja, nawiązując do reformy oświaty, oświadczył: osoba, która nie zna przeszłości swojej ojczyzny, nie będzie jej bronić, lecz sprzeda ja, jak podczas Targowicy oraz dodał patrioci analfabeci nie obronia niczego ${ }^{49}$. Specjalne stanowisko ws. reformy opublikował biskup Wiesław Mering (Przewodniczący Rady Konferencji Episkopatu Polski ds. Kultury i Ochrony Dziedzictwa Kulturowego). Oświadczył w nim, że odnosi wrażenie powtórki z historii: władza i jej organy prasowo-telewizyjne wiedzq najlepiej, jak prowadzić sprawy, nie konsultuja swoich decyzji ze społeczeństwem. W obliczu faktu, że w jego opinii historia zachęca, mobilizuje do myślenia, ale może też być niewygodna, groźna, zbędna, należy wyciągać wnioski z wydarzeń, które miały miejsce w XX w. i nie dopuścić do sytuacji podob-

\footnotetext{
${ }^{43}$ TuGRODZISK.pl codzienna gazeta internetowa, Przywrócić lekcje historii do szkól, http://www.tugrodzisk.pl/oswiata/przywrocic-lekcje-historii-do-szkol/, 28.08.2012 r.

44 Onet.pl Wiadomości, Kaczyński przeciwny zmianom w nauczaniu historii. ,, Ludzie będa głupsi”, http://wiadomosci.onet.pl/kraj/kaczynski-przeciwny-zmianom-w-nauczaniu-historii-1,1,5074823, wiadomosc.html, 28.08.2012 r.

45 Ibidem.

${ }^{46}$ Prawo i Sprawiedliwość, PiS złoży wniosek o wotum nieufności wobec minister Szumilas, http://www.pis.org.pl/ article.php?id=20227, 28.08.2012 r.

${ }^{47}$ WP.PL Wiadomości, Trwa sejmowa debata nad wnioskiem PiS o odwołanie Krystyny Szumilas, http://wiadomosci.wp.pl/kat,1342,title,Trwa-sejmowa-debata-nad-wnioskiem-PiS-o-odwolanie-Krystyny-Szumilas,wid,14514743, wiadomosc.html?ticaid=1f146, 28.08.2012 r.

${ }^{48}$ Onet.pl Wiadomości, Abp Michalik o reformie nauczania historii: to jest dramat, http://wiadomosci.onet.pl/kraj/abp-michalik-o-reformie-nauczania-historii-to-jest,1,5092679,wiadomosc.html, 28.08.2012 r.

${ }^{49}$ Radio Kielce, Biskup Kazimierz Ryczan broni historii w szkołach. Uroczystości 3 Maja w regionie, http://www.radio.kielce.pl/page,,Biskup-Kazimierz-Ryczan-broni-historii-w-szkolach-Uroczystosci-3-Maja-w-regionie,583bb3d28037630f4f7decef5418399a.html, 28.08.2012 r.
} 
nej do tej, w której Niemcy przestali myśleć, zaczęli maszerować. Swoje oświadczenie zakończył on słowami: Ufam, że Polacy myśleć nie przestana ${ }^{50}$.

Powyższe, krytyczne głosy wobec reformy, opierają się przede wszystkim na założeniu, że przedmiot historia i społeczeństwo, nie naucza historii (stąd podawana przez tę stronę informacja, że po ukończeniu pierwszej klasy IV etapu edukacyjnego uczniowie nie będą nauczani historii). Ponadto, głosy te można scharakteryzować jako przydające lekcjom historii funkcję kształtowania postaw patriotycznych, formowania wspólnoty narodowej ${ }^{51}$. Modyfikacje w obszarze edukacji historycznej określane są jako próba manipulowania historią, przyrównuje się je nawet do propagandy lub określa jako sprzyjające (a nawet mające decydujący wpływ) kształtowaniu człowieka podatnego na wpływy konsumenta dóbr, wartości wytworzonych przez ponadnarodowy kapitał. Część z krytyków uznała też za prostą kontynuację reformy, stworzenie w Polsce taniej siły roboczej dla krajów Europy Zachodniej.

Zwolennicy zmian w edukacji publicznej, o wiele rzadziej zabierali głos w dyskusji. Ich oceny były tożsame z komunikatami MEN. Odnosiły się przede wszystkim do faktu, że liczba godzin historii w IV etapie edukacyjnym nie zmniejszy się, a w określonych przypadkach zwiększy (nie uważają oni przedmiotu historia $i$ społeczeństwo za mniej wartościowy od przedmiotu historia - stanowi on dla nich jego kontynuację). Ponadto wielokrotnie, zapewne poszukując $w$ ten sposób legitymizacji, odwoływali się oni do reformy edukacji Jędrzejewicza z lat 30. XX w., której zamysły ta obecna ma urzeczywistnić ${ }^{52}$. Zaznaczali też, że uczeń o rok później, niż dotychczas, będzie dokonywać wyboru specjalizacji ${ }^{53}$. Ich oceny w sposób zwięzły zawiera felieton dziennikarki „Gazety Wyborczej” - Aleksandry Pezdy: Zmiany ida $w$ dobrym kierunku. Zwłaszcza podoba mi się ograniczenie tradycyjnej kronikarsko-propagandowej opowieści o królach i wojnach, na rzecz historii społeczeństw i kultury. To ważniejsze i bardziej pouczajace. Ale nie tudźmy się - mimo najlepszych chęci nauka historii najnowszej zawsze będzie skażona polityczna propaganda. Tak jest wszędzie. Prawda jest luksusem dla elit. Mimo że czeka w bibliotece na każdego. Za darmo ${ }^{54}$.

W uzupełnieniu do powyższych, należy nadmienić, że 27 września 2012 roku marszałek Sejmu Ewa Kopacz skierowała do posła Patryka Jaki - pełnomocnika Komitetu Inicjatywy Ustawodawczej Ustawy o zmianie ustawy o systemie oświaty, pismo zawiadamiające o skierowaniu projektu do pierwszego czytania ${ }^{55}$. Odbyło się ono 11 grudnia, jednak głosowanie nad wnioskiem o odrzucenie projektu ustawy przełożone zostało na 14 grudnia. Głosowało 430 posłów, za odrzuceniem opowiedziało się 218 (195 posłów z PO, 21 z PSL, 1 z PiS oraz

\footnotetext{
${ }^{50}$ Diecezja Włocławska, Stanowisko bp. Wiesława Meringa, Przewodniczqcego Rady KEP ds. Kultury i Ochrony Dziedzictwa Kulturowego $w$ sprawie lekcji historii $w$ polskich szkołach, http://www.diecezja.wloclawek.pl/pl/news/19, nauczanie-biskupa/458, stanowisko-bp-wieslawa-meringa-przewodniczacego-rady-kep-ds-kultury-i-ochrony-dziedzictwa-kulturowego-w-sprawie-lekcji-historii-w-polskich-szkolach, 28.08.2012 r.

51 Stanowiska zwolenników nauczania tzw. historii pozytywnej oraz jej wpływu na kształtowanie się tożsamości narodowej odnaleźć można w publikacji Pamięć i odpowiedzialność, red. R. Kostro, T. Merta, Kraków-Wrocław 2005.

${ }^{52}$ Ministerstwo Edukacji Narodowej, Podstawa programowa z komentarzami, t. 4..., op. cit.

${ }^{53}$ fronda.pl portal poświęcony, Ekspert MEN: Szanuję determinację głodujacych, wspótczuję ich małej wiedzy, http://www.fronda.pl/news/czytaj/tytul/ekspert_men:_szanuje_determinacje_glodujacych,_wspolczuje_ich_malej_wiedzy_19988, 28.08.2012 r.

${ }_{54}$ A. Pezda, Fikcyjne wykształcenie, śmieciowe umowy $i$ wielka frustracja młodych, http://wyborcza.pl/1,76842, 11468467,Fikcyjne_wyksztalcenie_smieciowe_umowy_i_wielka_frustracja.html\#ixzz25DPmw19A, 28.08.2012 r.

${ }^{55}$ Zawiadomienie o skierowaniu, wniesionego 20 września 2012 roku, projektu ustawy o zmianie ustawy o systemie oświaty do pierwszego czytania $w$ Sejmie (Druk nr 895, s. 9), http://www.sejm.gov.pl/sejm7.nsf/PrzebiegProc.xsp?id=9B68AA1BF05AF42DC1257ABD003B6972, 15.02.2013 r.
} 
1 niezależny), przeciw 209 (127 posłów z PiS, 40 z RP, 21 z SLD, 17 z SP, 2 z PO oraz 2 niezależnych). Dwóch członków klubu parlamentarnego PO i jeden PSL wstrzymało się od głosu. Tym samym projekt został odrzucony w pierwszym czytaniu ${ }^{56}$. W dniu następnym stowarzyszenie Ruch Edukacji Narodowej wydało oświadczenie, w którym zapowiedziało prowadzenie kolejnych akcji protestacyjnych ${ }^{57}$.

Podsumowując, ten społeczny i polityczny spór o kształt nauczania historii jest niezwykle interesującym badawczo, a zarazem ma unikatowy charakter. To pierwszy tak masowy protest przeciwko zmianom w obszarze nauczania jednego przedmiotu. Perspektywa czasowa pozwoli na jego dalszą analizę, szczególnie że nauczanie - jedna z najbardziej spornych kwestii - przedmiotu historia i społeczeństwo rozpocznie się dopiero we wrześniu roku szkolnego 2013/2014 (II klasa IV etapu edukacyjnego). Wówczas zapewne liczne kontrowersje wzbudzi wykaz podręczników dopuszczonych do użytku szkolnego w obszarze nauczania powyższego przedmiotu, tak jak to miało miejsce wcześniej w odniesieniu do podręczników do nauczania historii ${ }^{58}$.

\section{State, National, Social or Party History? Teaching History in Public Schools - a Case Study}

\section{Summary}

A canon of historical monuments, national holidays, names of streets, the provision of state financing to certain scientific and research centers, supporting initiatives to commemorate events and individuals, and building museums are only selected aspects of the historical policy of a state, approached as a detailed policy. This paper concerns another aspect of this policy, namely non-academic state education. A long-term educational reform was launched on September 1, 2009. It provides for the changes to be fully implemented by September 2014. They will concern a number of fields, but there is one that has become the core of a peculiar political conflict - the reform in teaching history. The paper presents the conflict, its turning points and, first and foremost, its rhetoric - the character of statements, selection of vocabulary and ways of evoking the right associations employed by both parties to the conflict. The paper also discusses the assumptions of the reform and indicates the most important legal acts and statements by the Minister of National Education, thereby providing a legal framework for the arguments of the conflicting parties.

\footnotetext{
${ }^{56}$ Gtosowanie $\mathrm{nr} 316$ - posiedzenie 30, pkt 16. porz. dzien. Pierwsze czytanie obywatelskiego projektu ustawy o zmianie ustawy o systemie oświaty - kontynuacja. Głosowanie nad przyjęciem wniosku o odrzucenie w pierwszym czytaniu obywatelskiego projektu ustawy o zmianie ustawy o systemie oświaty, zawartego w druku $\mathrm{nr} 895$, http:/www.sejm.gov.pl/sejm7.nsf/agent.xsp?symbol=glosowania\&nrkadencji=7\&nrposiedzenia=30\&nrglosowania=316, 15.02.2013 r.

${ }^{57}$ wPolityce.pl codziennie ważne informacje ze świata polityki, Oświadczenie Ruchu Edukacji Narodowej ws. odrzucenia przez Sejm obywatelskiego projektu o zmianie ustawy o systemie oświaty, http://wpolityce.pl/artykuly/42793-oswiadczenie-ruchu-edukacji-narodowej-ws-odrzucenia-przez-sejm-obywatelskiego-projektu-o-zmianieustawy-o-systemie-oswiaty, 15.02.2013 r.

58 wPolityce.pl codziennie ważne informacje ze świata polityki, UJAWNIAMY! MEN się nie cofnąt. Pełen manipulacji podręcznik dopuszczony do szkót. Znamy nazwiska recenzentów, http://wpolityce.pl/wydarzenia/28134-ujawniamy-men-sie-nie-cofnal-pelen-manipulacji-podrecznik-dopuszczony-do-szkol-znamy-nazwiska-recenzentow, 15.02.2013 r.
} 
